\title{
Density and Refractive Indices of Lactose Solutions
}

\section{By Emma J. McDonald and Anne L. Turcotte}

\begin{abstract}
The density and refractive indices of lactose solutions in the range of unsaturation are reported to five decimal places at $20^{\circ}$ and $25^{\circ} \mathrm{C}$. For solutions of higher concentration up to 50 -percent lactose, the corresponding values are reported at $25^{\circ} \mathrm{C}$ and for refractive indices alone at $15^{\circ} \mathrm{C}$.
\end{abstract}

\section{Introduction}

Lactose, the disaccharide commonly known as milk sugar, has for many years been of commercial importance. Until recently its principal use was in the manufacture of pharmaceuticals, food products, and in the preparation of modified diets; however, the penicillium industry now also requires large quantities of this sugar. ${ }^{1}$

In the present investigation measurements have been made to determine the density and refractive indices of lactose solutions. The tables here presented are expected to be of use to the investigator working with pure solutions as well as to the analyst dealing with solutions in which the total solids may be calculated as lactose.

\section{Preparation of Lactose}

The lactose used in this investigation was carefully prepared by repeated crystallizations of the commercial product. The procedure consisted in heating a 50-percent solution in a water bath at $90^{\circ} \mathrm{C}$, treating with decolorizing carbon, and filtering. The filtrate was then seeded with $a$-lactose hydrate crystals and stirred continuously while cooling in an ice bath. The resulting crystals, which were uniformly small and well formed, were purged on a centrifugal machine and washed consecutively with cold water and alcohol. After three crystallizations, the ash content had decreased to 0.002 percent and remained constant. The specific rotation of a-lactose hydrate in equilibrium solution is $+50.53^{\circ}$. Thus the direct reading of a 10 -percent solution would amount to $+30.35^{\circ}$. The effect of the last traces of impuri-

1 E. O. Whittier, J. Dairy Sci. 27, 505 (1944); a review, Lactose and its utilization, contains many references to work on lactose. ties on this reading is beyond the accuracy of the observations. Analysis by the method of Munson and Walker showed the product to be unchanged within the accuracy of the method. Here, as in the case of specific rotation, small traces of impurities would not affect the results noticeably. We, therefore, believe that ash content is a more reliable criterion for purity. The recrystallized product was dried in the air and stored in a desiccator over commercial $a$-lactose hydrate. Under these conditions the vapor pressure was so maintained that loss of water of crystallization was prevented.

Lactose hydrate contains 1 molecule of water of crystallization, which amounts to 5 percent of the total weight. Any change in the water of hydration would be reflected as an error in the percentage composition of the prepared solutions and hence in the reported physical constants; we, therefore, carefully investigated the composition of the crystals as to moisture content and were assured that we were dealing with a hydrate of uniform composition. Many moisture determinations were run in order to determine the most favorable conditions for this analysis.

The results obtained when the hydrate was dried in a vacuum at $85^{\circ}, 120^{\circ}$, and $130^{\circ} \mathrm{C}$ are shown in figure 1. In all cases the loss in water was accompanied by some decomposition of the sugar as indicated by a yellowing of the sample. This discoloration was more pronounced in the recrystallized sugar than in the original commercial product. Because the ash content decreased on recrystallization from 0.0135 to 0.002 percent, it is suggested that a buffering material is present in the commercial product and that this retards decomposition. The minimum discolora- 

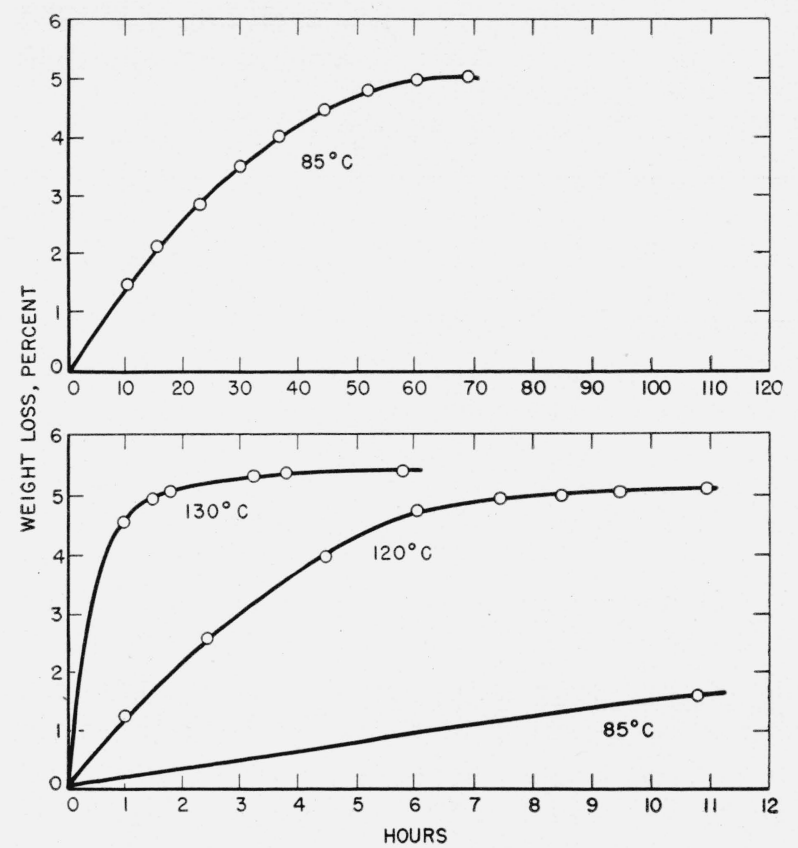

Figure 1. Dehydration of $\alpha$-lactose hydrate at $85^{\circ}, 120^{\circ}$, and $130^{\circ} \mathrm{C}$ in vacuum.

tion during loss of water appeared to take place at $120^{\circ} \mathrm{C}$, and, therefore, this temperature was subsequently used in determining the moisture content. The drying curves shown in figure 2 are representative of those obtained during the progress of the investigation. Inspection of these curves shows the danger of using an arbitrary time when determining the moisture content of any given sample of $\alpha$-lactose hydrate.

\section{Physical Measurements}

The range in concentration where accurate density and refractive index measurements can be made is limited by the relatively low solubility of lactose and by the readiness with which supersaturated solutions tend to deposit crystals. At $20^{\circ} \mathrm{C}$, a saturated solution of lactose contains 16 percent of sugar, a low value as compared with 49,67 , and 70 , the respective percentages of saturated dextrose, sucrose, and levulose solutions at this temperature. Supersaturated solutions deposit lactose hydrate crystals with great ease and thus limit the reliability of measurements made upon them. We have, therefore, carried out density and refractive index measurements with high precision in the range of unsaturation. The values reported for supersaturated solutions, although not obtained with the same precision, are suitable for many purposes and thus are included in this investigation.

\section{Density of Lactose Solutions}

Density measurements were made in a carefully calibrated flask. When filled to the lowest graduation at $20^{\circ} \mathrm{C}$, this flask contained $126.333 \mathrm{ml}$. Its neck, 6-mm inside diameter, was graduated in 10 divisions at intervals of $0.02 \mathrm{ml}$. The volume reading could be estimated to one-tenth of one of these divisions, thus permitting a precision slightly greater than two units in the fifth place of density. The flask was recalibrated from time to time during the progress of the investigation, and the volume was found to be constant within the error of reading.

A quantity of $\alpha$-lactose hydrate was introduced

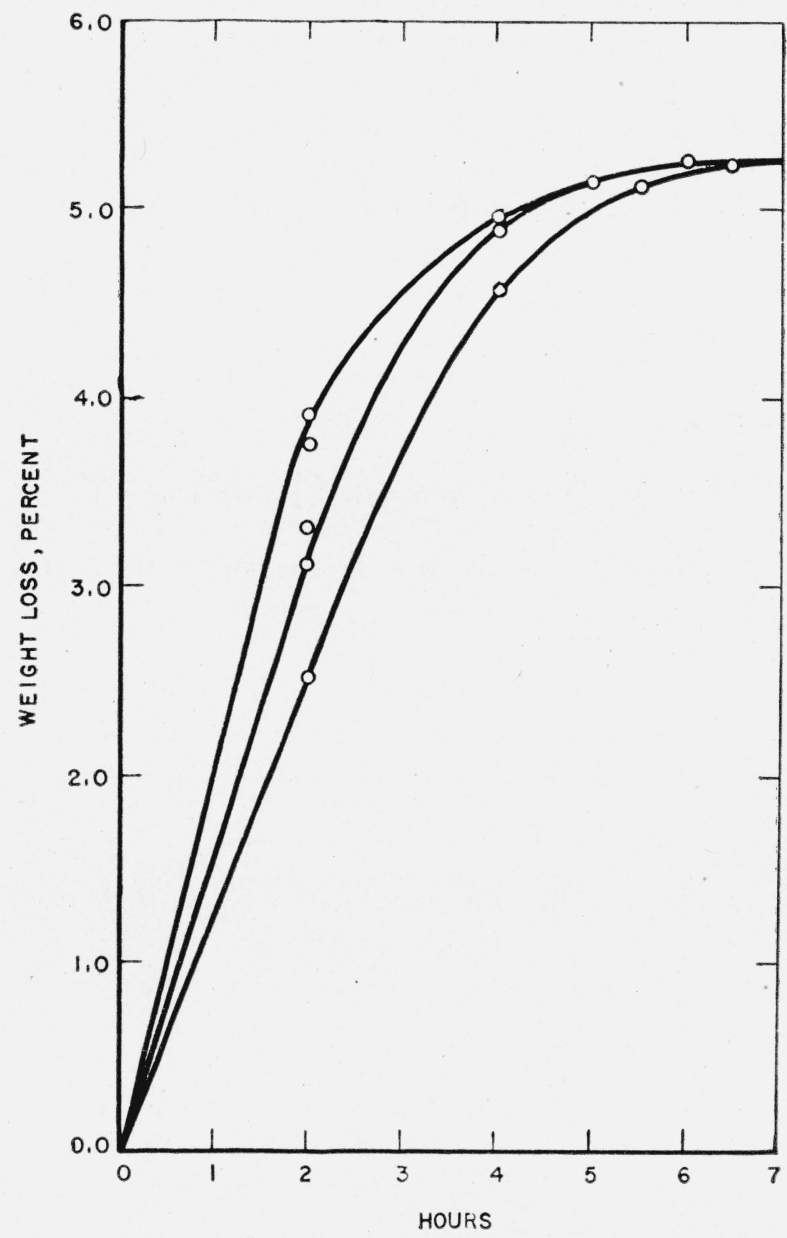

Figure 2. Dehydration of $\alpha$-lactose hydrate at $120^{\circ} \mathrm{C}$ in vacuum. 
into the weighed flask and accurately weighed. The sugar was dissolved in distilled water and air removed from the solution. The latter was accomplished by placing the slightly warmed flask in an environment of reduced pressure, care being taken to avoid spattering during this procedure. Water was then added to some point within the graduation, and the flask was rotated in such a way that the solution did not wet the upper part of the neck of the flask. After removing the water adhering to the flask above the solution by means of a current of dry air, the flask was placed in a thermostat and the final volume taken when the solution had come to temperature. As the manipulation was timeconsuming, mutarotation was completed before the final observation of volume. ${ }^{2}$

At the time of each weighing, the density of the air in the balance case was determined by weighing a glass bulb, whose true mass had been determined at this Bureau. All weights were reduced to vacuum, the value for the density of solid $\alpha$-lactose hydrate being taken as 1.540 in accordance with the determinations recorded below.

The experimental data are assembled in tables 1 and 2. From these observed values the following equations were calculated by the method of least squares. Here the density of a lactose solution is expressed as a function of the percentage, $(p)$, of $\alpha$-lactose present.

$$
\begin{aligned}
& D_{4}^{20}=0.99823+0.003739 p+0.00001281 p^{2} . \\
& D_{4}^{25}=0.99707+0.003717 p+0.00001263 p^{2} .
\end{aligned}
$$

The deviation of the observed values from those calculated by formula are given in the last column of each table. The observed values show a mean deviation of less than 3 in the fifth place at $20^{\circ} \mathrm{C}$, and less than 2 at $25^{\circ} \mathrm{C}$, from those calculated by formula. We, therefore, believe that the formulas are valid to some units in the fifth decimal.

The values now given in the literature for the density of lactose solutions have been determined in connection with specific rotation studies. The work of Schmoeger, ${ }^{3}$ as well as that of Fleischmann and Weigner, ${ }^{4}$ will be considered because these

\footnotetext{
2 The procedure used in making the density determinations was essentially that described by Jackson and Matthews in their work on levulose; BS J. Research 8, 405 (1932) R P426.

${ }^{3}$ M. Schmoeger, Ber, deut. chem. Ges. 13, 1922 (1880).

4 W. Fleischmann and G. Weigner, J. Landw. 58, 45 (1910).
}

\begin{tabular}{|c|c|c|c|c|c|c|c|}
\hline $\begin{array}{l}\text { Weight } \\
\text { of lac- } \\
\text { tose } 1 \\
\text { (air brass } \\
\text { wt.) }\end{array}$ & $\begin{array}{l}\text { Weight } \\
\text { of lac- } \\
\text { tose } \\
\text { (vacu- } \\
\text { um) }\end{array}$ & $\begin{array}{c}\text { Weight } \\
\text { of solu- } \\
\text { tion } \\
\text { (vacu- } \\
\text { um) }\end{array}$ & $\begin{array}{l}\text { Volume } \\
\text { of solu- } \\
\text { tion }\end{array}$ & $\begin{array}{l}\text { Con- } \\
\text { centra- } \\
\text { tion of } \\
\text { lactose }\end{array}$ & $\begin{array}{c}D_{4}^{20} \\
\text { observed }\end{array}$ & $\begin{array}{c}D_{4}^{20} \\
\text { calcu- } \\
\text { lated by } \\
\text { form- } \\
\text { ula }^{2}\end{array}$ & $\begin{array}{c}\text { Devia- } \\
\text { tion } \\
\text { from } \\
\text { formula }\end{array}$ \\
\hline$g$ & $g$ & $g$ & $m l$ & Percent & & & \\
\hline 2. 2413 & 2. 2427 & 126. 9997 & 126.381 & 1. 766 & 1. 00490 & 1. 00487 & +0.00003 \\
\hline 2. 7596 & 2. 7613 & 127.1586 & 126. 344 & 2.172 & 1. 00644 & 1. 00641 & +.00003 \\
\hline 5.8969 & 5. 9004 & 128.3891 & 126.405 & 4. 596 & 1.01570 & 1. 01569 & +.00001 \\
\hline 10. 9203 & 10.9268 & 130. 2569 & 126.404 & 8. 389 & 1. 03048 & 1. 03050 & -.00002 \\
\hline 15.8408 & 15. 8502 & 132.1234 & 126.444 & 11. 996 & 1. 04492 & 1. 04493 & -.00001 \\
\hline 17.1718 & 17. 1903 & 132.6147 & 126.442 & 12. 963 & 1. 04882 & 1. 04885 & -.00003 \\
\hline 23. 5294 & 23.5441 & 134.9147 & 126. 398 & 17.451 & 1. 06738 & 1. 06738 & 0 \\
\hline 24.0298 & 24.0450 & 135.1012 & 126.402 & 17. 798 & 1. 06884 & 1. 06884 & 0 \\
\hline 25. 3294 & 25. 3444 & 135. 6730 & 126.493 & 18. 681 & 1. 07357 & 1. 07255 & +.00002 \\
\hline
\end{tabular}

TABLe 1. Density of lactose solutions at $20.0^{\circ} \mathrm{C}$

${ }^{1} \alpha$-lactose hydrate.

${ }^{2} D_{4}^{20}=0.99823+0.003739 p+0.00001281 p^{2}$.

\begin{tabular}{|c|c|c|c|c|c|c|c|}
\hline $\begin{array}{c}\text { Weight } \\
\text { of lac- } \\
\text { tose } 1 \\
\text { (air brass } \\
\text { wt.) }\end{array}$ & $\begin{array}{l}\text { Weight } \\
\text { of lac- } \\
\text { tose } \\
\text { (vacu- } \\
\text { um) }\end{array}$ & $\begin{array}{l}\text { Weight } \\
\text { of solu- } \\
\text { tion } \\
\text { (vacu- } \\
\text { um) }\end{array}$ & $\begin{array}{l}\text { Volume } \\
\text { of solu- } \\
\text { tion }\end{array}$ & $\begin{array}{c}\text { Con- } \\
\text { centra- } \\
\text { tion of } \\
\text { lactose }\end{array}$ & $\begin{array}{c}D_{4}^{25} \\
\text { observed }\end{array}$ & $\begin{array}{c}D_{4}^{25} \\
\text { calcu- } \\
\text { lated by } \\
\text { form- } \\
\text { ula }^{2}\end{array}$ & $\begin{array}{l}\text { Devia- } \\
\text { tion } \\
\text { from } \\
\text { formula }\end{array}$ \\
\hline$g$ & $g$ & $g$ & $m l$ & Percent & & & \\
\hline 1. 0643 & 1. 0650 & 126.4207 & 126. 390 & 0.843 & 1. 00024 & 1. 00021 & +0.00003 \\
\hline 1. 8585 & 1. 8596 & 126.7549 & 126. 432 & 1. 467 & 1. 00255 & 1. 00255 & 0 \\
\hline 5. 2778 & 5. 2810 & 128.0341 & 126.436 & 4. 125 & 1. 01264 & 1. 01262 & +.00002 \\
\hline 8.1789 & 8. 1838 & 129.1437 & 126.470 & 6. 337 & 1. 02114 & 1. 02113 & +.00001 \\
\hline 10. 2912 & 10. 2974 & 129.9499 & 126.496 & 7. 924 & 1.02730 & 1. 02732 & -.00002 \\
\hline 15. 1632 & 15.1723 & 131.7102 & 126.457 & 11. 519 & 1. 04154 & 1.04157 & $-.00 v 03$ \\
\hline 20.1185 & 20.1306 & 133.5434 & 126.463 & 15. 074 & 1. 05599 & 1. 05598 & +.00001 \\
\hline
\end{tabular}

TABle 2. Density of lactose solutions at $25.0^{\circ} \mathrm{C}$

${ }^{1} \alpha$-lactose hydrate.

${ }^{2} D_{4}^{25}=0.99707+0.003717 p+0.00001263 p^{2}$.

investigators extended their observations to supersaturated solutions. Schmoeger reported values for the density of lactose solutions containing as much as 36 percent of the sugar. His values are given in the fourth place. Fleischmann and Weigner obtained data on solutions containing as much as 69 percent of sugar. The latter authors report that great difficulty was encountered in preparing solutions of the higher concentrations, and hence only few observations were made. We believe that the inclusion of density values on supersaturated solutions, although they cannot be obtained with great precision, may be of value to investigators working with this sugar. Therefore, we have applied the method of least squares to the data presented by these early investigators on supersaturated solutions for concentrations as high as 50 percent and obtained the following 
equation relating the density to the percentage concentration.

$$
D_{4}^{20}=0.9982+0.00370 p+0.0000150 p^{2} .
$$

Tables 3 and 4 are working tables containing density values for unsaturated solutions and for saturated solutions of concentrations up to 50 percent. The values for unsaturated solutions are based on eq 1 and 2, and those for the supersaturated solutions were calculated by use of eq 3.

TABle 3. Density of lactose solutions at $20^{\circ}$ and $25^{\circ} \mathrm{C}$

\begin{tabular}{|c|c|c|c|c|}
\hline$\alpha$-Lactose hydrate & $D_{4}^{20_{1}}$ & $D_{4}^{25_{2}}$ & $\begin{array}{c}\alpha \text {-Lactose } \\
\text { hydrate }\end{array}$ & $D_{4}^{20_{3}}$ \\
\hline Percent & & & Percent & \\
\hline $0 \ldots$ & 0.89823 & 0.99707 & 20 & 1. 0782 \\
\hline $1 \ldots \ldots$ & 1.00198 & 1. 00080 & $22 \ldots$ & 1. 0869 \\
\hline $2 \ldots$ & 1.00576 & 1. 00456 & 24 & 1. 0956 \\
\hline $3 \ldots$ & 1.00956 & 1. 00834 & 26 & 1. 1045 \\
\hline $4 \ldots \ldots$ & 1.01339 & 1. 01214 & $28 \ldots$ & 1. 1136 \\
\hline 5 & 1.01725 & 1. 01597 & $30 \ldots$ & 1. 1227 \\
\hline 6 & 1.02113 & 1. 01983 & $32 \ldots$ & 1. 1320 \\
\hline $7 \ldots$ & 1.02503 & 1. 02371 & 34 & 1. 1414 \\
\hline $8 \ldots$ & 1.02896 & 1.02762 & $36 \ldots$ & 1. 1509 \\
\hline $9 \ldots \ldots$ & 1.03292 & 1. 03155 & $38 \ldots$ & 1. 1605 \\
\hline $10 \ldots$ & 1.03690 & 1. 03551 & $40 \ldots$ & 1. 1702 \\
\hline $11 \ldots$ & 1.04091 & 1. 03949 & $42 \ldots$ & 1. 1801 \\
\hline $12 \ldots$ & 1.04494 & 1. 04350 & $44 \ldots$ & 1. 1900 \\
\hline $13 \ldots$ & 1.04900 & 1. 04753 & $46 \ldots$ & 1. 2001 \\
\hline 14 & 1.05309 & 1.05159 & $48 \ldots$ & 1. 2104 \\
\hline $15 \ldots$ & 1.05720 & 1,05568 & 50 & 1. 2207 \\
\hline 16 & 1. 06138 & 1. 05978 & - & -.... \\
\hline $17 \ldots \ldots$ & 1.06550 & 1. 06392 & - & - n. \\
\hline $18 \ldots$ & 1. 06968 & - n & n...... & ...... \\
\hline
\end{tabular}

${ }_{1} D_{4}^{20}=0.99823+0.003739 p+0.00001281 p^{2}$.

${ }^{2} D_{4}^{25}=0.99707+0.0037175 p+0.00001263 p^{2}$.

${ }_{3} D_{4}^{20}=0.9982+0.00370 p+0.0000150 p^{2}$.

\section{Density of Crystalline Lactose}

The density of the crystalline $\alpha$-lactose hydrate ${ }^{5}$ was required in order to convert the weight in air to weight in vacuum.

The lactose was weighed in a calibrated flask, and the flask was filled with dry toluene saturated with lactose at $20^{\circ} \mathrm{C}$. The trapped air was removed from the crystals by applying gentle suction while rotating the flask. All weights were reduced to the vacuum standard. The results of

${ }^{5}$ Previous values (E. O. von Lippmann, Chemie Der Zuckerarten, p. 1526 (von Friedrick Vieweg und Sohn (1904)); Lichtenstein 1.543, Boedeker 1.5384, Filhol 1.534, Joule and Playfair 1.530, and Pionchon 1.525 (C. S. Hudson and F. C. Brown, J. Am. Chem. Soc. 30, 960 (1908)), Hudson and Brown 1.54 (sp gr $\alpha$-lactose hydrate) 1.59 (sp gr $\beta$-lactose).
TABLE 4. Density of lactose solutions at $20^{\circ} \mathrm{C}$

\begin{tabular}{|c|c|c|c|}
\hline $\begin{array}{l}\text { Anhydrous } \\
\text { lactose }\end{array}$ & $D_{4}^{20}$ & $\begin{array}{l}\text { Anhdyrous } \\
\text { lactose }\end{array}$ & $D_{4}^{20}$ \\
\hline Percent & & Percent & \\
\hline $1 \ldots \ldots$ & 1. 00218 & $18 \ldots \ldots$ & 1. 07367 \\
\hline $2 \ldots \ldots$ & 1. 00616 & $20 \ldots$ & 1. 0827 \\
\hline $3 \ldots \ldots$ & 1. 01016 & $22 \ldots$ & 1. 0919 \\
\hline $4 \ldots \ldots$ & 1. 01420 & $24 \ldots$ & 1. 1012 \\
\hline $5 \ldots$ & 1. 01824 & $26 \ldots$ & 1. 1107 \\
\hline $6 \ldots$ & 1. 02236 & $28 \ldots$ & 1. 1203 \\
\hline $7 \ldots$ & 1.02647 & $30 \ldots$ & 1. 1300 \\
\hline $8 \ldots$ & 1. 03062 & $32 \ldots$ & 1. 1399 \\
\hline $9 \ldots \ldots$ & 1. 03480 & $34 \ldots$ & 1. 1498 \\
\hline 10 & 1. 03901 & $36 \ldots$ & 1. 1600 \\
\hline $11 \ldots$ & 1. 04324 & $38 \ldots$ & 1. 1702 \\
\hline 12 & 1. 04750 & $40 \ldots$ & 1. 1806 \\
\hline $13 \ldots$ & 1. 05179 & $42 \ldots \ldots$ & 1. 1911 \\
\hline 14 & 1. 05611 & $44 \ldots \ldots$ & 1. 2017 \\
\hline 15 & 1. 06046 & $46 \ldots$ & 1. 2125 \\
\hline $16 \ldots$ & 1. 06484 & $48 \ldots$ & 1. 2234 \\
\hline 17 & 1. 06924 & $50 \ldots$ & 1. 2345 \\
\hline
\end{tabular}

these measurements are given in table 5 . The density of lactose hydrate was found to be 1.540 . The density of commercial $\beta$-lactose, an anhydrous form that has found extensive commercial use because of its greater solubility, was found to be 1.589 .

\section{Refractive Indices}

The refractive indices of unsaturated solutions of lactose at $20^{\circ}$ and $25^{\circ} \mathrm{C}$ were determined by use of a carefully calibrated immersion refractometer under accurately controlled conditions of temperature. All measurements were made in a constanttemperature room whose temperature was maintained within 2 degrees of that at which the water in the bath surrounding the instrument was beld.

The instrument was inserted in a large glass tube, $83 \mathrm{~mm}$ in diameter and $350 \mathrm{~mm}$ in length. This contained sufficient water to surround the instrument cup containing the sugar solution. The glass tube with the suspended instrument was placed in a constant-temperature water bath, so that only a small part of it extended above the surface of the water. A thermometer was placed beside the instrument. Illumination was supplied by an electric bulb submerged in a glass tube similar to that containing the refractometer. The floor of the bath reflected the light into the instrument. Under these conditions a very sharp line characteristic of total refraction was observed, 


\begin{tabular}{|c|c|c|c|c|c|c|c|c|}
\hline $\begin{array}{l}\text { Weight of } \\
\text { pure } \\
\text { toluene } \\
\text { (vacuum) }\end{array}$ & $\begin{array}{l}\text { Volume } \\
\text { toluene }\end{array}$ & $\begin{array}{c}D_{4}^{20_{1}} \\
\text { toluene }\end{array}$ & $\begin{array}{c}\text { Weight } \\
\alpha \text {-lactose } \\
\text { hydrate } \\
\text { (vacuum) }\end{array}$ & $\begin{array}{l}\text { Weight } \\
\text { toluene } \\
\text { (vacuum) }\end{array}$ & $\begin{array}{c}\text { Total } \\
\text { volume }\end{array}$ & $\begin{array}{l}\text { Volume } \\
\text { toluene }\end{array}$ & $\begin{array}{c}\text { Volume } \\
\alpha \text {-lactose } \\
\text { hydrate }\end{array}$ & $\begin{array}{c}D_{4}^{20} \\
\alpha \text {-lactose } \\
\text { hydrate }\end{array}$ \\
\hline$g$ & $m l$ & & $g$ & $g$ & $m l$ & $m l$ & $m l$ & \\
\hline 86.6441 & 100.2355 & 0.86441 & 19. 1054 & 98.5649 & 126.4265 & 114. 0243 & 12.4022 & 1. 5405 \\
\hline 86.5196 & 100.0915 & .86441 & 19. 1054 & 98.6121 & 126. 4838 & 114. 0789 & 12. 4049 & 1. 5401 \\
\hline 86.6413 & 100.2285 & .86444 & 19. 1054 & 98.5252 & 126. 3883 & 113.9784 & 12. 4099 & 1. 5395 \\
\hline 86.5947 & 100.1765 & .86442 & 20.0613 & 97.9627 & 126.3597 & 113.3277 & 13.0320 & 1. 5394 \\
\hline \multirow[t]{2}{*}{86.5650} & 100.1425 & .86442 & - & ......... & ......... & ......... & - & ........... \\
\hline & avg & 0.86442 & & & & & & \\
\hline 86.6176 & 100.1685 & .86472 & 10. 2736 & 103.5757 & 126. 4532 & 119. 7836 & 6. 6696 & 1. 5404 \\
\hline 86.6241 & 100.1805 & .86468 & 10. 2736 & 103.5025 & 126. 3692 & 119. 6989 & 6. 6703 & 1. 5402 \\
\hline \multirow[t]{3}{*}{86.5739} & 100.1235 & .86467 & - & - & . & . & - & . \\
\hline & avg & 0.86469 & & & & & avg & 1.5400 \\
\hline & & & $\begin{array}{c}\text { Weight } \\
\beta \text {-lactose } \\
\text { (vacuum) }\end{array}$ & & & & $\begin{array}{l}\text { Volume } \\
\beta \text {-lactose }\end{array}$ & $\begin{array}{c}D_{4}^{20} \\
\beta \text {-lactose }\end{array}$ \\
\hline - & -.. & 0.86469 & 22.8752 & 96.8837 & 126. 4704 & 112. 0794 & 14. 3910 & 1. 5895 \\
\hline - & . & .86469 & 22.8752 & 96. 7750 & 126.3501 & 111. 9537 & 14. 3964 & 1. 5890 \\
\hline \multirow[t]{2}{*}{....... } & . & .86469 & 22.8752 & 96.8459 & 126.4265 & 112.0357 & 14. 3908 & 1. 5896 \\
\hline & & & & & & & $\operatorname{avg} \ldots$ & 1. 5893 \\
\hline
\end{tabular}

\footnotetext{
1 Samples of toluene from two different lots were used for these experiments. The density of toluene recorded in the determinations on $\beta$-lactose is the average value for the second lot of reagent.
}

permitting a precision of a few hundredths and an estimated accuracy of 0.1 to 0.2 of a scale division in the reading of the instrument.

The conversion tables supplied by the manufacturer are based on readings for distilled water. In accordance with these tables, the instrument was set at 14.50 at $20^{\circ} \mathrm{C}$ and at 13.25 at $25^{\circ} \mathrm{C}$. These readings are equivalent to indices of 1.33299 at $20^{\circ} \mathrm{C}$ and 1.33252 at $25^{\circ} \mathrm{C}$. Readings on distilled water were made frequently, thus insuring the setting of the instrument. The arbitrary scale readings were converted to refractive indices by use of the manufacturer's tables.

Equations relating the refractive index to the concentration were prepared by subjecting the observed data to the method of least squares.

$$
\begin{gathered}
n_{D}^{20}=1.33299+0.001409 p+0.00000498 p^{2} \\
n_{D}^{25}=1.33251+0.001405 p+0.000004805 p^{2} .
\end{gathered}
$$

Tables 6 and 7 contain the observed data as well as those calculated by formula.

\begin{tabular}{|c|c|c|c|c|c|c|c|}
\hline $\begin{array}{l}\text { Weight } \\
\text { of lac- } \\
\text { tose } 1 \\
\text { (air } \\
\text { brass } \\
\text { wt) }\end{array}$ & $\begin{array}{l}\text { Weight } \\
\text { of lac- } \\
\text { tose } \\
\text { (vac- } \\
\text { uum) }\end{array}$ & $\begin{array}{l}\text { Weight } \\
\text { of solu- } \\
\text { tion (vac- } \\
\text { uum) }\end{array}$ & $\begin{array}{c}\text { Con- } \\
\text { centra- } \\
\text { tion of } \\
\text { lactose }\end{array}$ & $\begin{array}{c}\text { Zeiss im- } \\
\text { mersion } \\
\text { scale } \\
\text { reading } \\
t=20.0^{\circ} \mathrm{C}\end{array}$ & $\begin{array}{c}n_{D}^{20} \\
\text { observed }\end{array}$ & $\begin{array}{c}n_{D}^{20} \\
\text { calcu- } \\
\text { lated by } \\
\text { formula? }\end{array}$ & $\begin{array}{c}\text { Devia- } \\
\text { tion } \\
\text { from } \\
\text { formula }\end{array}$ \\
\hline$g$ & 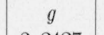 & $g$ & Percent & & & & \\
\hline 2. 2413 & 2. 2427 & 126.9997 & 1.766 & 21.00 & 1. 33551 & 1.33549 & +0.00002 \\
\hline 3.3207 & 3. 3227 & 127.3975 & 2. 608 & 24.12 & 1. 33671 & 1.33669 & +.00002 \\
\hline 5. 2365 & 5. 2397 & 101. 7278 & 5. 151 & 33.74 & 1. 34038 & 1.34038 & \\
\hline 7.3119 & 7.3162 & 102. 5546 & 7. 134 & 41.47 & 1.34330 & 1.34329 & +.00001 \\
\hline 15. 1730 & 15. 1819 & 131. 8051 & 11.518 & 59.10 & 1. 34988 & 1. 34988 & 0 \\
\hline 15. 2437 & 15. 2525 & 131.8654 & 11. 567 & 59.30 & 1. 34995 & 1.34996 & -.00001 \\
\hline 22. 2235 & 22. 2367 & 134. 4964 & 16. 533 & 80.41 & 1.35765 & 1.35764 & +.00001 \\
\hline
\end{tabular}

TaвLE 6. Refractive indices of lactose solutions at $20.0^{\circ} \mathrm{C}$

${ }^{1} \alpha$-lactose hydrate.

${ }^{2} n_{D}^{20}=1.33299+0.001409 p+0.00000498 p^{2}$ 。

The refractive indices of supersaturated solutions at $25^{\circ} \mathrm{C}$, as well as those of all concentrations at $15^{\circ} \mathrm{C}$, were determined with an Abe refractometer. The scale of the instrument used permitted readings to a few units in the fourth decimal place. This was the limiting factor in the precision of the readings, since they were all made 
TABLE 7. Refractive indices of lactose solutions at $25.0^{\circ} \mathrm{C}$

\begin{tabular}{|c|c|c|c|c|c|c|c|}
\hline $\begin{array}{l}\text { Weight } \\
\text { of lac- } \\
\text { tose } 1 \\
\text { (air } \\
\text { brass } \\
\text { wt) }\end{array}$ & $\begin{array}{l}\text { Weight } \\
\text { of lac- } \\
\text { tose } \\
\text { (vac- } \\
\text { uum) }\end{array}$ & $\begin{array}{l}\text { Weight } \\
\text { of solu- } \\
\text { tion (vac- } \\
\text { uum) }\end{array}$ & $\begin{array}{l}\text { Con- } \\
\text { centra- } \\
\text { tion of } \\
\text { lactose }\end{array}$ & $\begin{array}{c}\text { Zeiss im- } \\
\text { mersion } \\
\text { scale } \\
\text { reading } \\
t=20.0^{\circ} \mathrm{C}\end{array}$ & $\begin{array}{c}n_{D}^{25} \\
\text { observed }\end{array}$ & $\begin{array}{c}n_{D}^{25} \\
\text { calcu- } \\
\text { lated by } \\
\text { formula }\end{array}$ & $\begin{array}{l}\text { Devia- } \\
\text { tion } \\
\text { from } \\
\text { formula }\end{array}$ \\
\hline$g$ & $g$ & $g$ & Percent & & & & \\
\hline 1. 0643 & 1. 0650 & 126.4207 & 0.843 & 16.32 & 1. 33371 & 1. 33370 & +0.00001 \\
\hline 2. 5473 & 2. 5498 & 127.0832 & 2.006 & 20.54 & 1. 33534 & 1. 33535 & -.00001 \\
\hline 5. 2778 & 5. 2810 & 128,0341 & 4.125 & 28.54 & 1. 33841 & 1. 33839 & +.00002 \\
\hline 8. 1789 & 8. 1838 & 129.1437 & 6.337 & 36.90 & 1. 34158 & 1. 34160 & -.00002 \\
\hline 10. 2912 & 10. 2974 & 129.9499 & 7.924 & 43.20 & 1. 34396 & 1. 34395 & +.00001 \\
\hline 15. 1632 & 15. 1723 & 131. 7102 & 11.519 & 57. 63 & 1. 34933 & 1. 34933 & 0 \\
\hline 20.1185 & 20.1306 & 133.5434 & 15.074 & 72.46 & 1. 35478 & 1. 35478 & 0 \\
\hline
\end{tabular}

${ }^{1} \alpha$-lactose hydrate.

$2 n_{D}^{25}=1.33251+0.001405 \mathrm{p}+0.000004805 p^{2}$.

under carefully controlled conditions. Equations 6 and 7 are based upon these data.

$$
\begin{gathered}
n_{D}^{25}=1.3325+0.001384 p+0.00000624 p^{2} \\
n_{D}^{15}=1.3334+0.001412 p+0.00000537 p^{2} .
\end{gathered}
$$

The observed data for indices of refraction and also the values calculated by the formulas are given in tables 8 and 9 . Table 10 is included as a working table. It has been prepared by use of the proper formula for each temperature.

TABLE 8. Refractive indices of lactose solutions at $25^{\circ} \mathrm{C}$

\begin{tabular}{|c|c|c|c|c|c|c|}
\hline \hline $\begin{array}{c}\text { Weight } \\
\text { of lac- } \\
\text { tose 1 (air } \\
\text { brass } \\
\text { wt) }\end{array}$ & $\begin{array}{c}\text { Weight } \\
\text { of lac- } \\
\text { tose } \\
\text { (vac- } \\
\text { uum) }\end{array}$ & $\begin{array}{c}\text { Weight } \\
\text { of solu- } \\
\text { tion } \\
\text { (vacuum) }\end{array}$ & $\begin{array}{c}\text { Concen- } \\
\text { tration of } \\
\text { lactose }\end{array}$ & $\begin{array}{c}n_{4}^{25} \\
\text { observed } \\
\text { Abbé }\end{array}$ & $\begin{array}{c}n_{4}^{25} \text { cal- } \\
\text { culated } \\
\text { by for- } \\
\text { mula 2 }\end{array}$ & $\begin{array}{c}\text { Devia- } \\
\text { tion from } \\
\text { formula }\end{array}$ \\
\cline { 1 - 3 }$g$ & $g$ & $g$ & Percent & & & - \\
10.9856 & 10.9923 & 53.7058 & 20.468 & 1.3634 & 1.3634 & 0.0000 \\
14.0010 & 14.0095 & 54.9307 & 25.504 & 1.3720 & 1.3719 & +.0001 \\
17.1285 & 17.1389 & 56.6435 & 30.257 & 1.3800 & 1.3800 & .0000 \\
20.2416 & 20.3139 & 56.8220 & 35.750 & 1.3899 & 1.3900 & -.0001 \\
\hline
\end{tabular}

$1 \alpha$-lactose hydrate.

${ }^{2} n_{D}^{25}=1.3325+0.001384 p+0.00000624 p^{2}$.
TABLE 9. Refractive indices of lactose solutions at $15^{\circ} \mathrm{C}$

\begin{tabular}{|c|c|c|c|c|c|c|}
\hline $\begin{array}{c}\text { Weight } \\
\text { of lac- } \\
\text { tose } 1 \text { (air } \\
\text { brass } \\
\text { wt.) }\end{array}$ & $\begin{array}{c}\text { Weight } \\
\text { of lac- } \\
\text { tose } \\
\text { (vac- } \\
\text { uum) }\end{array}$ & $\begin{array}{c}\text { Weight } \\
\text { of solu- } \\
\text { tion } \\
\text { (vacuum) }\end{array}$ & $\begin{array}{c}\text { Concen- } \\
\text { tration of } \\
\text { lactose }\end{array}$ & $\begin{array}{c}n_{4}^{15} \\
\text { observed } \\
\text { Abbé }\end{array}$ & $\begin{array}{c}n_{4}^{15} \text { cal- } \\
\text { culated } \\
\text { by for- } \\
\text { mula }\end{array}$ & $\begin{array}{c}\text { Devia- } \\
\text { tion from } \\
\text { formula }\end{array}$ \\
\hline$g$ & $g$ & $g$ & Percent & & - & - \\
\hline$g .6839$ & 2.6855 & 50.7500 & 5.292 & 1.3410 & 1.3410 & 0.0000 \\
13.1331 & 13.1412 & 131.1152 & 10.023 & 1.3480 & 1.3480 & .0000 \\
26.3086 & 26.3248 & 136.0419 & 19.351 & 1.3629 & 1.3627 & +.0002 \\
33.1227 & 33.1431 & 138.4840 & 23.933 & 1.3701 & 1.3703 & -.0002 \\
39.6613 & 39.6857 & 141.0027 & 28.145 & 1.3772 & 1.3774 & -.0002 \\
52.8430 & 52.8755 & 145.7118 & 36.288 & 1.3919 & 1.3917 & +.0002 \\
\hline
\end{tabular}

${ }_{1} \alpha$-lactose hydrate.

${ }^{2} n_{D}^{15}=1.3334+0.001412 p+0.00000537 p^{2}$.

\begin{tabular}{|c|c|c|c|c|}
\hline $\begin{array}{c}\alpha \text {-Lactose } \\
\text { hydrate }\end{array}$ & $n_{D}^{25}$ & $n_{D}^{20}$ & $n_{D}^{15}$ & $\Delta n / \Delta t$ \\
\hline Percent & & & & \\
\hline $1 \ldots$ & 1. 33392 & 1. 33440 & 1. 3348 & 0.000096 \\
\hline $2 \ldots$ & 1. 33534 & 1. 33583 & 1. 3362 & .000098 \\
\hline $3 \ldots$ & 1. 33677 & 1. 33726 & 1. 3376 & .000098 \\
\hline $4 \ldots$ & 1. 33821 & 1. 33871 & 1. 3391 & .000100 \\
\hline $5 \ldots$ & 1. 33966 & 1. 34016 & 1. 3406 & .000100 \\
\hline $6 \ldots$ & 1. 34111 & 1. 34162 & 1. 3421 & .000102 \\
\hline $7 \ldots$ & 1. 34258 & 1. 34310 & 1. 3436 & .000104 \\
\hline $8 \ldots \ldots$ & 1. 34406 & 1. 34458 & 1.3451 & .000104 \\
\hline $9 \ldots$ & 1. 34554 & 1. 34607 & 1. 3466 & .000106 \\
\hline $10 \ldots$ & 1. 34704 & 1. 34758 & 1. 3481 & .000108 \\
\hline $11 \ldots$ & 1. 34855 & 1. 34909 & 1.3496 & .000108 \\
\hline $12 \ldots$ & 1. 35006 & 1. 35062 & 1. 3511 & .000112 \\
\hline $13 \ldots$ & 1. 35159 & 1. 35215 & 1. 3526 & .000112 \\
\hline $14 \ldots$ & 1. 35312 & 1. 35369 & 1. 3542 & .000116 \\
\hline $15 \ldots$ & 1. 35467 & 1. 35524 & 1. 3558 & .000116 \\
\hline $16 \ldots$ & 1. 35622 & 1. 35681 & 1. 3573 & .000118 \\
\hline $18 \ldots$ & 1. 3594 & - & 1. 3605 & .00011 \\
\hline $20 \ldots$ & 1. 3627 & - & 1. 3637 & .00010 \\
\hline $22_{-.-}$ & 1. 3660 & - & 1. 3670 & .00010 \\
\hline $24 \ldots$ & 1. 3693 & - & 1. 3703 & .00010 \\
\hline $26 \ldots$ & 1. 3727 & -. & 1. 3737 & .00010 \\
\hline $28 \ldots$ & 1. 3762 & ...... & 1. 3770 & .00008 \\
\hline $30 \ldots$ & 1.3797 & - & 1.3805 & .00008 \\
\hline $32 \ldots$ & 1. 3832 & - & 1. 3839 & .00007 \\
\hline $34 \ldots$ & 1. 3868 & - & 1. 3875 & .00007 \\
\hline $36 \ldots$ & 1. 3904 & - & 1. 3910 & .00006 \\
\hline
\end{tabular}

TABLE 10. Refractive indices of lactose solutions

Washington, January 27, 1948. 